\title{
Sistem Keamanan Ruang Menggunakan Kamera Bergerak
}

\author{
Supriadi Syam ${ }^{1}$ dan Muslim ${ }^{2}$ \\ ${ }^{I}$ Sistem Informasi, STMIK Handayani, ${ }^{2}$ Teknik Informatika, STMIK Handayani \\ supriadisyam@handayani.ac.id,muslim@handayani.ac.id \\ Coprespondent Author : Supriadi Syam
}

\begin{abstract}
Security systems are important things that are needed by a person or an agency in securing something important. During this time the use of CCTV cameras became the main choice, but the camera can only take pictures in one direction only. The purpose of the study was to create a prototype space security system that focused on securing the room from moving objects. This condition will clarify the characteristics of moving objects and the camera cannot be manipulated to face the other way. The research stage that will be done is to prepare a room that will be a security room, engineer a python program to recognize moving objects in the space, engineer programs to make the camera follow the movement of the object with a large angle of $180^{\circ}$ controlled with arduino. The result of this study is that the system can detect movement with a maximum distance of 7 meters and the system can communicate with arduino that moves the camera towards the moving object.
\end{abstract}

Keyword - System, Security, Camera, Python

Abstrak - Sistem keamanan merupakan hal penting yang dibutuhkan seseorang atau suatu instansi dalam mengamankan sesuatu yang penting. Selama ini penggunaan kamera CCTV menjadi pilihan utama, namun kamera tersebut hanya dapat mengambil gambar ke satu arah saja. Tujuan dari penelitian ini adalah untuk membuat sebuah prototipe sistem keamanan ruang yang berfokus pada pengamanan ruangan dari adanya objek yang bergerak. Kondisi ini akan memperjelas ciri-ciri objek yang bergerak dan kamera tidak dapat dimanipulasi untuk menghadap ke arah lain. Tahapan penelitian yang akan dilakukan adalah menyiapkan ruangan yang akan menjadi ruang pengamanan, merekayasa program python untuk mengenali objek bergerak pada ruang tersebut, merekayasa program untuk membuat kamera mengikuti pergerakan objek tersebut dengan besar sudut $180^{\circ}$ yang dikontrol dengan arduino. Hasil penelitian ini adalah sistem dapat mendeteksi gerakan dengan jarak maksimal 7 meter serta sistem dapat berkomunikasi dengan arduino yang menggerakkan kamera ke arah objek yang bergerak.

Kata kunci - Sistem, Keamanan, Kamera, Python

\section{PENDAHULUAN}

Keamanan merupakan salah satu kebutuhan, baik keamanan diri maupun barang-barang berharga yang dimiliki. Banyak pilihan cara yang digunakan untuk mengamankan barang berharga, mulai dari asuransi, membuat ruang penyimpanan khusus, menggunakan teknologi tertentu untuk menjaga atau menyewa penjaga.

Semakin meningkatnya tingkat kejahatan seperti pencurian dan perampokan yang terjadi baik di lingkungan rumah, toko maupun tempat yang berpotensi membuat kita harus meningkatkan keamanan. Karena itu keamanan menjadi salah satu aspek penting yang tidak bisa lepas dalam kehidupan sehari-hari. Banyak cara yang dapat digunakan untuk meningkatkan keamanan, mulai dari mekanisme tata ruang, penggunaan satpam, pengawasan menggunakan aplikasi satu pintu dan pengawasan jarak jauh yang biasa menggunakan kamera.[1] Salah satu teknologi yang sering digunakan adalah memasang kamera pengawas. Kelebihan dari cara ini adalah cenderung lebih murah karena dapat digunakan dalam jangka waktu lama. Namun kekurangannya adalah kamera ini hanya akan menyorot wilayah sesuai dengan jangkauannya saat dipasang. Tentunya untuk keperluan pengamanan harus ada orang yang siap 24 jam untuk memandangi layar monitor. Jika tidka menggunakan penjaga maka kamera ini dengan mudah dapat dibelokkan arah sorotannya. Penelitian ini bertujuan untuk membuat suatu prototipe sistem keamanan berbasis kamera yang dapat bergerak saat ada objek lain yang bergerak di dalam ruangan atau jika ada yang membelokkan arah sorotannya. Urgensi penelitian ini terletak pada peringatan dini saat ada pergerakan di ruangan yang sedang dijaga atau saat ada yang membelokkan arah sorotan dari kamera. Dengan menggunakan kamera bergerak, orang yang bergerak di ruangan tersebut menjadi fokus sorotan. Gerakan adalah suatu pusat perhatian yang digunakan manusia ataupun hewan untuk mengenali suatu obyek dari suatu latar yang tidak teratur. Deteksi gerakan secara sederhana dapat dilakukan dengan mencari beda antara dua buah citra yang berurutan pada hasil pencitraan menggunakan kamera video digital.[1]

\section{METODE PENELITIAN}

Metode yang digunakan dalam penelitian ini adalah metode Software Development Life Cycle (SDLC) dengan model Waterfall yang secara umum terdiri dari analisis, desain, pengkodean dan pengujian.[2] Model tersebut kami susun sebagai berikut:

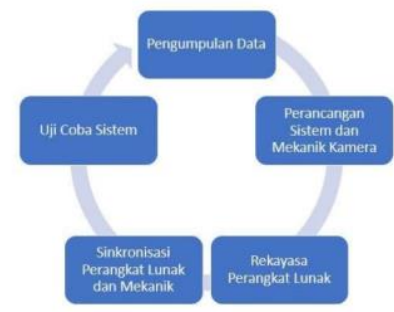

Gambar 1. Model SDLC 


\section{A. Pengumpulan Data}

Data yang dikumpulkan berupa data referensi cara deteksi gerakan yang akan dikenali oleh kamera. Cara yang digunakan adalah dengan membandingkan gambar hasil capture kamera dengan hasil capture berikutnya menggunakan Open CV.[3] Langkah-langkah yang dilakukan sebagai berikut:

1. Pengalokasian gambar

2. Pengambilan frame pada background

3. Perhitungan rata-rata perbedaan nilai frame tiap pixel

4. Menentukan nilai batas atas berdasarkan perbedaan nilai rata-rata tiap frame

5. Segmentasi gambar foreground

6. Penghapusan memori tiap kali selesai menggunakan background

\section{B. Perancangan Sistem dan Mekanik Kamera}

Sistem dirancang menggunakan UML yang menampilkan Use Case dan Activity Diagram. Mekanik yang dirancang menggunakan 1 unit servo dan arduino sebagai kontroller.

\section{Use case Diagram}

Diagram use case disajikan untuk memperlihatkan apa saja yang bisa dilakukan sistem dan apa yang user bisa lakukan terhadap sistem.[4]

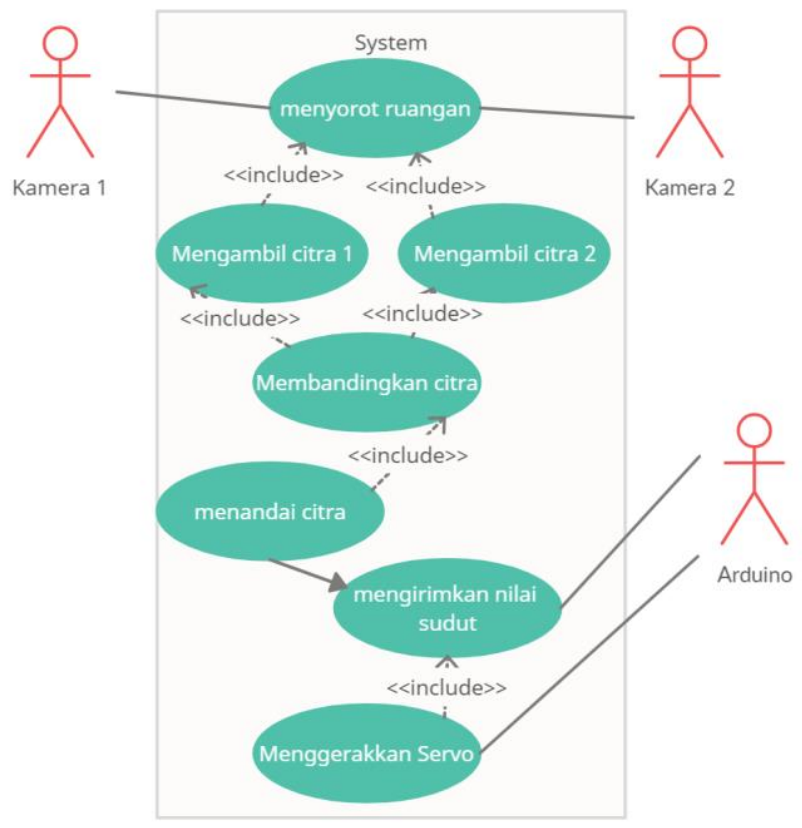

Gambar 2 Use Case Diagram

\section{Activity Diagram}

Diagram activity digunakan untuk menunjukkan tahapan proses sistem dari awal sampai menghasilkan keluaran.

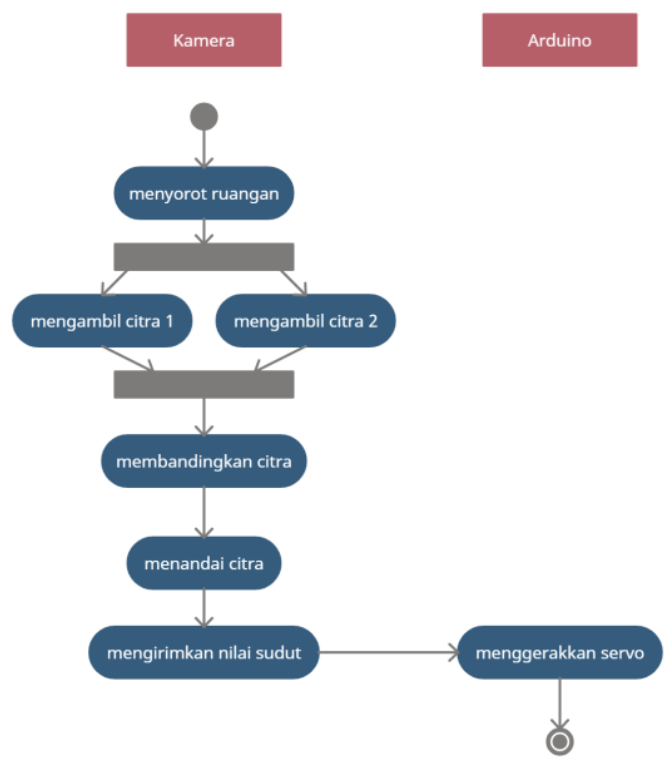

Gambar 3 Activity Diagram

3. Arduino dan Servo

Arduino merupakan sebuah perangkat open source dan merupakan kombinasi dari hardware, bahasa pemrograman dan IDE.[5] Pada penelitian ini juga digunakan Servo yang merupakan kombinasi rangkaian elektronika dan motor listrik. Servo mampu membuat gerakan berputar $180^{\circ}$ yang diperlukan kamera untuk menyorot pergerakan objek.

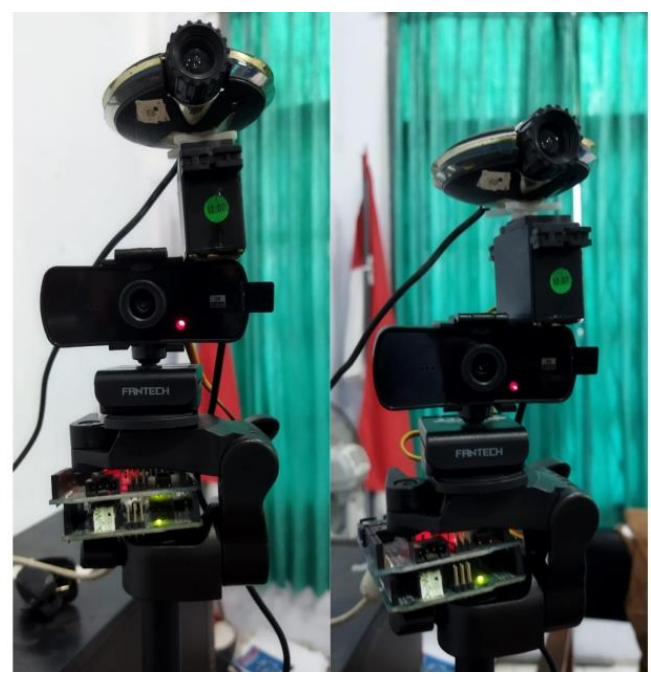

Gambar 4. Mekanik Kamera menggunakan servo 


\section{Rekayasa Perangkat Lunak}

Perangkat Lunak dibangun dengan menggunakan bahasa pemrograman Python dan memanfaatkan library Open $C V$ dan pyFirmata.

\section{from pyfirmata import Arduino, SERVO \\ from time import sleep \\ from pyfirmata.pyfirmata import pin \\ from pyfirmata.util import pin_list_to_board_dict}

Gambar 5 Deklarasi pyFirmata pada Python

\section{Sinkronisasi Perangkat Lunak dan Mekanik}

Perangkat lunak yang dibuat disinkronkan dengan mekanik dengan mengakses RX TX pada Arduino dan bekerja pada jalur serial. Port arduino pada komputer disesuaikan dengan pembacaan pada IDE arduino serta pin digital yang digunakan oleh servo di deklarasikan sesuai posisi pin servo pada arduino.

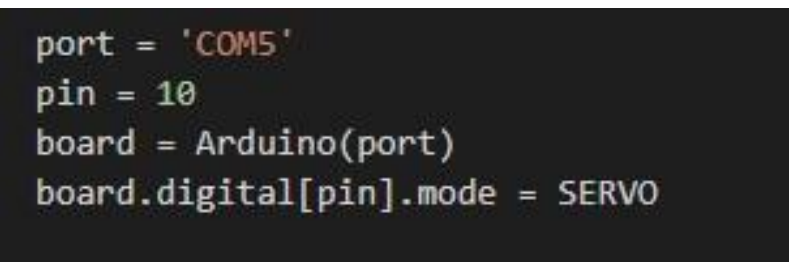

Gambar 6 Sinkronisasi arduino dengan perangkat lunak

\section{E. Uji Coba Sistem}

Sistem di uji coba secara keseluruhan dengan mensimulasikan sebuah ruangan dan kamera sebagai pemantau ruangan. Kemudian disimulasikan dengan adanya orang yang masuk ke ruangan.

1. Ruangan simulasi

Ruangan yang digunakan adalah sebuah laboratorium komputer dengan posisi kamera berada pada bagian depan sudut atas ruangan.

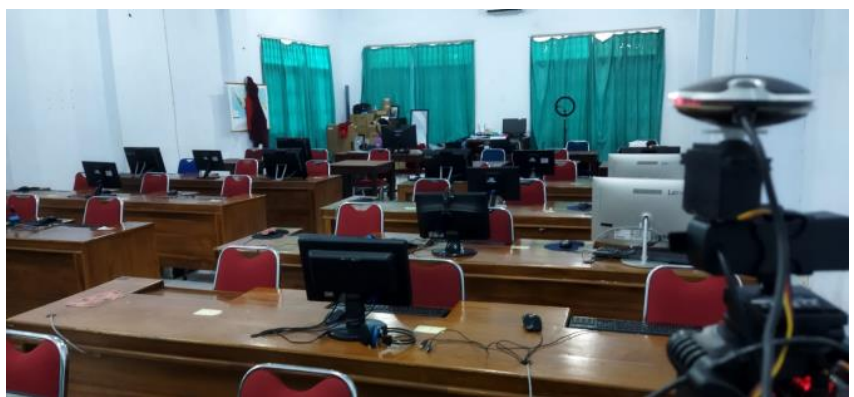

Gambar 7 Ruangan simulasi

\section{Perangkat lunak}

Perangkat lunak yang dibuat menggunakan bahasa pemrograman python dijalankan menggunakan komputer. Komputer inilah yang akan memproses citra digital yang ditangkap kamera dan mendeteksi gerakan serta meneruskan perintah ke arduino jika terdeteksi gerakan.

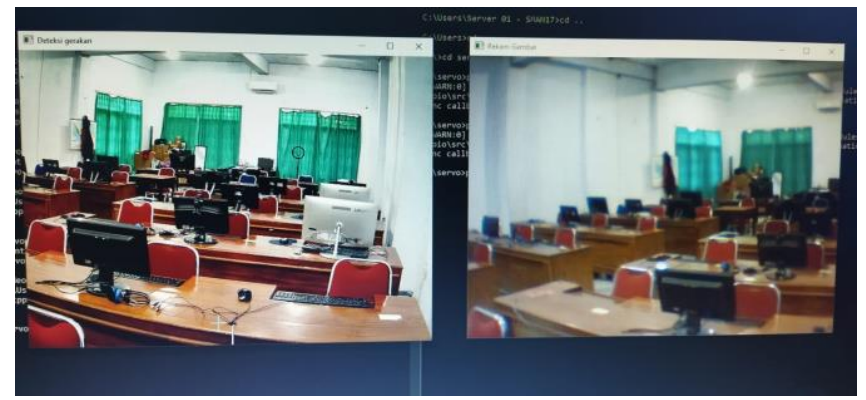

Gambar 8 Tampilan Perangkat Lunak

\section{HASIL DAN PEMBAHASAN}

Hasil pengujian sistem dilakukan dengan mengukur kemampuan sistem mendeteksi gerakan pada jarak tertentu. Jika gerakan terdeteksi maka pada layar monitor akan ditampilkan segiempat berwarna hijau yang mengelilingi objek yang bergerak. Selain itu di saat berhasil mendeteksi objek yang bergerak, sistem mengirim perintah kepada arduino untuk memutar servo kamera ke arah objek yang bergerak. Kamera pertama akan terus menyorot ruangan secara statis, dan kamera kedua akan menyorot objek yang bergerak secara kontinyu.

\section{A. Deteksi Gerakan}

Gerakan dideteksi dengan membandingkan nilai grayscale citra yang diterima dengan nilai grayscale citra citra sebelumnya.[1]

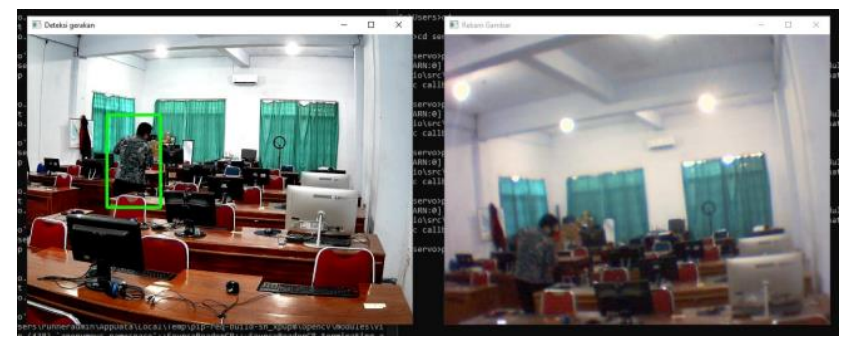

Gambar 9. Deteksi Gerakan

Sistem yang dibuat memanfaatkan method absdiff yang dimiliki Open $C V$ untuk membandingkan citra. Citra sebelumnya diubah menjadi grayscale. 


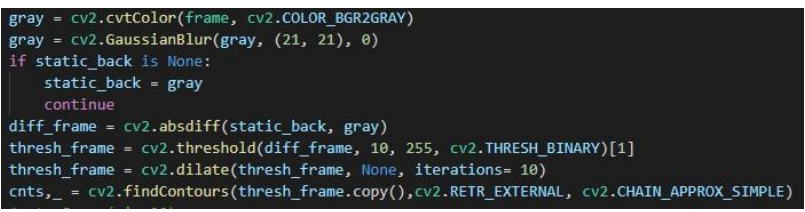

Gambar 10. Penggunaan absdiff open $c v$

TABEL I

PENGUJIAN DETEKSI GERAKAN

\begin{tabular}{|c|l|c|}
\hline No. & \multicolumn{1}{|c|}{ Jarak } & Ket \\
\hline 1 & 1 Meter & Berhasil \\
\hline 2 & 2 Meter & Berhasil \\
\hline 3 & 3 Meter & Berhasil \\
\hline 4 & 4 Meter & Berhasil \\
\hline 5 & 5 Meter & Berhasil \\
\hline 6 & 6 Meter & Berhasil \\
\hline 7 & 7 Meter & Berhasil \\
\hline 8 & 8 Meter & Tidak terdeteksi \\
\hline 9 & 9 Meter & Tidak terdeteksi \\
\hline 10 & 10 meter & Tidak terdeteksi \\
\hline
\end{tabular}

Berdasarkan tabel di atas kemampuan maksimal sistem mendeteksi gerakan berada pada jarak 7 meter.

\section{B. Gerakan Kamera}

Kamera digerakkan dengan memanfaatkan pyFirmata yang sebelumnya diinstalasi ke dalam python. Sistem menggunakan beberapa method dari pyFirmata untuk berkomunikasi dengan arduino. Sistem ini memanfaatkan method ARDUINO, SERVO, pin dan pin_list_to_board_dict.

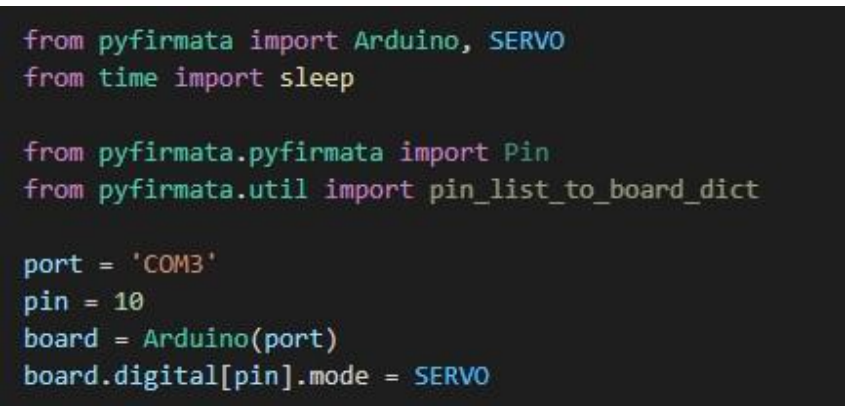

Gambar 11. Deklarasi pyFrimata

Kemudian dibuat sebuah prosedur yang berfungsi untuk memutar servo sesuai sudut yang diberikan sistem.

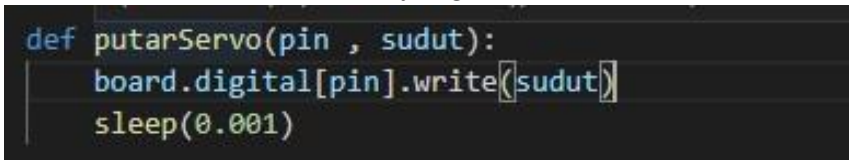

Gambar 12. Deklarasi prosedur putarServo

Sudut yang diberikan sistem berasal dari posisi $x$ ditambah dengan lebar objek bergerak kemudian dikalikan dengan
180 yang merupakan besar sudut maksimal yang dapat dijangkau servo.

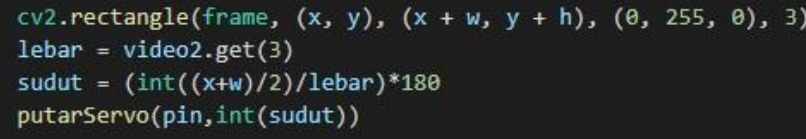

Gambar 13. Perhitungan sudut putaran servo

\section{KESIMPULAN DAN SARAN}

A. Kesimpulan

Dari hasil implementasi dan uji coba sistem, dapat ditarik kesimpulan sebagai berikut:

1) Sistem dapat mendeteksi gerakan pada jarak maksimal 7 meter.

2) Kecepatan pergerakan kamera dapat di atur dengan memberi delay pembacaan citra.

3) Sistem dapat berkomunikasi dengan arduino tanpa harus membuat program khusus pada arduino itu sendiri.

B. Saran

Dari hasil penelitian yang dilakukan, penulis memberikan beberapa saran untuk peneliti berikutnya yaitu:

1) Penggunaan kamera resolusi tinggi dapat menambah jarak pembacaan gerakan pada sistem.

2) Membuat sistem dapat membedakan antara makhluk hidup yang bergerak dengan benda mati.

3) Menggunakan kamera yang memiliki fasilitas night vision untuk pengawasan dalam kondisi intensitas cahaya yang kurang.

\section{DAFTAR ACUAN}

[1] S. T. Widyardini, Pemrograman Matlab untuk Pengolahan Citra Digital: Studi Kasus Sistem Pemantau Ruangan Pengganti CCTV. Universitas Brawijaya Press, 2015.

[2] S. Syam, 'Prototipe Alat Ukur Dan Rekam Kadar Hara Tanah Sawah Menggunakan Sensor Warna', J. IT Media Inf. STMIK Handayani Makassar, vol. 8, no. 3, pp. 136-143, 2017.

[3] A. Saleh, 'Gerakan Animasi Manusia Berdasarkan Isyarat Tangan Berbasis Pengolahan Citra'. OSF Preprints, May 07, 2021. doi: 10.31219/osf.io/psvyz.

[4] S. Syam, 'Aplikasi Tuntunan Penggunaan Peralatan Praktikum Kimia Berbasis Multimedia', J. IT Media Inf. STMIK Handayani Makassar, vol. 8, no. 2, pp. 78-83, 2017.

[5] N. J. N. Jamal and S. Siswanto, 'Monitoring Keamanan Ruang Berbasis Arduino Dan Android Menggunakan Kamera Vc0706 Dan Sensor Suhu Dht-11', SKANIKA, vol. 1, no. 3, pp. 1219-1224, 2018. 